Article

\title{
Levels of Aflatoxin M1 in Breast Milk of Lactating Mothers in Monterrey, Mexico: Exposure and Health Risk Assessment of Newborns
}

\author{
Rogelio Salas ${ }^{1, *}$, Nallely Acosta ${ }^{1}$, Aurora de Jesús Garza ${ }^{2}$, Alexandra Tijerina ${ }^{1} \mathbb{D}$, Roberto Dávila ${ }^{2}$, \\ Zacarías Jiménez-Salas ${ }^{1}{ }^{\mathbb{D}}$, Laura Otero ${ }^{1}$, Mirna Santos ${ }^{1}$ and Antonio-José Trujillo ${ }^{3}{ }^{\mathbb{B}}$
}

check for

updates

Citation: Salas, R.; Acosta, N.; Garza, A.d.J.; Tijerina, A.; Dávila, R.; Jiménez-Salas, Z.; Otero, L.; Santos, M.; Trujillo, A.-J. Levels of Aflatoxin M1 in Breast Milk of Lactating Mothers in Monterrey, Mexico: Exposure and Health Risk Assessment of Newborns. Toxins 2022, 14, 194. https://doi.org/ $10.3390 /$ toxins 14030194

Received: 8 February 2022

Accepted: 2 March 2022

Published: 5 March 2022

Publisher's Note: MDPI stays neutral with regard to jurisdictional claims in published maps and institutional affiliations.

Copyright: (C) 2022 by the authors. Licensee MDPI, Basel, Switzerland. This article is an open access article distributed under the terms and conditions of the Creative Commons Attribution (CC BY) license (https:// creativecommons.org/licenses/by/ $4.0 /)$.
1 Centro de Investigación en Nutrición y Salud Pública (CINSP), Facultad de Salud Pública y Nutrición, Universidad Autónoma de Nuevo León, Monterrey 64460, Mexico; nallely.acostae@uanl.edu.mx (N.A.); alexandra.tijerinas@uanl.mx (A.T.); zacarias.jimenezsl@uanl.edu.mx (Z.J.-S.); laura.oterobtst@uanl.edu.mx (L.O.); mirna.santosl@uanl.mx (M.S.)

2 Department of Biochemistry and Molecular Medicine, Facultad de Medicina, Universidad Autónoma de Nuevo León, Monterrey 64460, Mexico; aurora.garzajr@uanl.edu.mx (A.d.J.G.); roberto.davilacnl@uanl.edu.mx (R.D.)

3 Centre d'Innovació, Recerca i Transferència en Tecnologia dels Aliments (CIRTTA), TECNIO-UAB, XIA, Departament de Ciència Animal i dels Aliments, Facultat de Veterinària, Universitat Autònoma de Barcelona, 08193 Bellaterra, Spain; toni.trujillo@uab.es

* Correspondence: rogelio.salasg@uanl.mx

\begin{abstract}
The present study aimed to determine the presence of the aflatoxin M1 (AFM1) in breast milk samples from 123 nursing women and the degree of exposure of infants to this toxin, in the metropolitan area of Monterrey, Nuevo Leon state (northeast Mexico). Upon analysis, $100 \%$ of the samples were found to be contaminated with the toxin at an average concentration of $17.04 \mathrm{ng} / \mathrm{L}$, with a range of 5.00 to $66.23 \mathrm{ng} / \mathrm{L}$. A total of $13.01 \%$ of the breast milk samples exceeded the regulatory limit of $25 \mathrm{ng} / \mathrm{L}$ for AFM1 concentration, set by the European Union. The estimated daily intake for AFM1 and the carcinogenic risk index were also determined in the 0- to 6-, 7- to 12-, 13- to 24-, and 25- to 36-month-old age groups. The AFM1 intake through breast milk ranged from 1.09 to $20.17 \mathrm{ng} / \mathrm{kg}$ weight/day, and was higher than the tolerable daily intake, indicating a carcinogenic risk for infants in the age groups of 0 - to 24-months old. This evidence demonstrates a susceptibility of breast milk to AFM1 contamination that may suggest a carcinogenic risk for the breastfed infants in Monterrey city, Nuevo Leon state, and the need to control the presence of aflatoxins in foods eaten by nursing mothers.
\end{abstract}

Keywords: aflatoxin M1; breast milk; AFM1 daily intake; infant population; carcinogenic risk; Monterrey (Mexico)

Key Contribution: This is the first contribution realized in the northeast of Mexico, and the second nationally, to demonstrate a potential health risk associated with the aflatoxin M1 (AFM1) for infants through breast milk intake.

\section{Introduction}

Breast milk is considered as the best food for neonates and infants [1], being a complex biofluid rich in nutrients (e.g., macronutrients, micronutrients, trace elements, etc.) and non-nutritive bioactive components (e.g., cells, immunoglobulins, cytokines, chemokines, hormones, growth factors, etc.) [2,3]. Breast milk contains a variety of bioactive compounds that contribute to proper brain, intestinal, and immune development [4]. The World Health Organization recommends exclusive breastfeeding for the first six months of life, continued until two years of life or longer [5]. 
Breast milk exhibits composition variability among individuals, and it is possible to find the presence of compounds that harm the health of the infant, such as aflatoxins [6]. Aflatoxins (AF) are considered toxic metabolites produced by some molds such as $A s-$ pergillus flavus, A. parasiticus and A. nomius [7]. In humans, ingestion of the secondary metabolite AFB1 can lead to the accumulation and excretion of the aflatoxin M1 (AFM1) in breast milk through the ingestion of contaminated food sources, such as corn and derived products, nuts, dairy, sunflower oil, bread, and whole grain cereals [8,9].

AFM1 has been associated with carcinogenic, mutagenic, teratogenic, estrogenic, immunotoxic, nephrotoxic, and neurotoxic effects [8]. In addition, exposure to AFM1 in children has been associated with Reye's and Kwashiorkor's syndromes, immunosuppression, dermal irritation, endocrine disruptions, acute hepatitis, and others metabolic disturbances such as non-alcoholic liver disease [10-12]. Aflatoxin toxicity is related to intestinal barrier function $[13,14]$. It has been reported that when aflatoxin is present, there is a disruption of the intestinal barrier, which contributes to oxidative stress and DNA damage [14], and to an inflammatory response [13,14], causing a risk to health.

At present, there is limited scientific evidence on the presence of AFM1 in the breast milk of nursing mothers that have probably been exposed to diets containing AFB1 in Mexico, and the hazards of its presence. The aim of this study was to determine the occurrence and levels of AFM1 in breast milk, the exposure of infants to AFM1, and the potential carcinogenic risks associated with its consumption in the Monterrey population.

\section{Results and Discussion}

This is a first study to demonstrate the presence and concentration of AFM1 in breast milk from mothers in the northeast of Mexico, Nuevo Leon state. In terms of the presence of AFM1 in breast milk, the toxin was detected in $100 \%$ of the studied samples $(n=123)$, similar to the results reported from previous studies in other countries [15]. The presence of AFM1 in breast milk is directly related to the consumption habits of lactating mothers due to the pattern of foods they eat, which are different depending on the country. Diets composed of cereals, spices, seeds, oils and nuts, and cow-milk products can be contaminated with AFB1 and AFM1 to a greater or lesser extent depending on several environmental, storage, and climatic conditions that may affect AF production and the contamination of foods with AFB1 [16].

The current literature reports a highly variable occurrence and concentration of AFM1 in breast milk, with certain studies presenting high incidences (100\%) such as Gambia and Tanzania [17], Iran [18], the Ecuadorian highlands [19], and Jordan [20], while medium or low occurrences have been reported in Portugal (33\%), Ghana (22\%), Italy and Cameroon $(5 \%)$, and Brazil (4\%) [21-24].

Table 1 shows the average, and minimum and maximum AFM1 concentrations found breast milk samples, according to the infant age group. The average concentration of AFM1 in breast milk samples was $17.04 \pm 9.13 \mathrm{ng} / \mathrm{L}$ and ranged from 5.00 to $66.23 \mathrm{ng} / \mathrm{L}$. Although the average AFM1 concentration in the analyzed breast milk samples did not exceed the tolerance limit of $25 \mathrm{ng} / \mathrm{L}$ set by the European Commission for infant formula [25], 13.01\% of the individual samples exceeded this limit. On the other hand, it was observed that the breast milk samples collected from nursing mothers at different stages of lactation (age groups) showed similar AFM1 contents in the groups from 0 to 24 months-old, while the AFM1 content of breast milk in the group from 25 to 36 months-old had the lower mean level, although these differences were not significant.

The mean AFM1 levels detected in this study were among of those previously reported in other countries with moderate AFM1 concentrations, such as Turkey (32.83 ng/L), Nigeria (22.33 ng/L), Italy (12.98 ng/L), Brazil (12.01 ng/L) [26], Kuwait (9.7 ng/L) [27], Cyprus (7.84 ng/L) [28], Portugal (7.12 ng/L) [29], Iran (6.80 ng/L) [30], Gambia (5.65 ng/L), Colombia (5.20 ng/L) [31], and Lebanon (4.31 ng/L) [32], but far from the high concentration levels reported by different studies in the United Arab Emirates (210-4060 ng/L) [33], Egypt (7100 ng/L) [34], Sudan (401 ng/L) [35], and Serbia (370 ng/L) [36]. In a study from 
central Mexico, $89 \%$ of breast milk samples $(n=112)$ showed the presence of AFM1 at a concentration of $10.35 \mathrm{ng} / \mathrm{L}$ (range of $3.01-34.24 \mathrm{ng} / \mathrm{L}$ ), and $7 \%$ of samples exceeded the recommended limit of $25 \mathrm{ng} / \mathrm{L}$ [9].

Table 1. Aflatoxin M1 (AFM1) presence in breast milk.

\begin{tabular}{cccc}
\hline \multirow{2}{*}{ Age Group (Months) } & $\boldsymbol{n}(\boldsymbol{\%}) *$ & Mean \pm SD & Min-Max \\
\hline 0 to 6 & $86(9.30)$ & $16.68 \pm 9.66$ & $5.00-66.23$ \\
7 to 12 & $18(22.22)$ & $17.92 \pm 8.45$ & $5.00-38.26$ \\
13 to 24 & $16(25.00)$ & $18.96 \pm 7.49$ & $5.00-29.21$ \\
25 to 36 & $3(00.00)$ & $11.96 \pm 3.46$ & $8.16-14.93$ \\
Total & $123(13.01)$ & $17.04 \pm 9.13$ & $5.00-66.23$ \\
\hline
\end{tabular}

* $n$ is the number of samples of breast milk collected for each age group. The value in parentheses indicates the samples' percentage above the limit set by the European Union ( $25 \mathrm{ng} / \mathrm{L})$ with respect to the total.

Table 2 shows the estimated daily intake (EDI; means, and minimum and maximum) of AFM1 through breast milk, and the potential carcinogenic risk index (CRI) according to the equation proposed by Kuiper-Goodman (1994) [37]. Considering the mean AFM1 levels, body weight, and milk intakes of each age group of infants, the EDI values ranged from 1.81 to $5.08 \mathrm{ng} / \mathrm{kg}$ weight/day. The youngest group, from 0- to 6-months old, had the highest AFM1 EDI values, showing the susceptibility of this group of infants; EDI values slighly diminished in the subsequent age groups, with the infant group of 25- to 36-months old having the lowest exposure, due to a higher body weight and a lower consumption of breast milk.

Table 2. Estimated daily intake (EDI) of aflatoxin M1 and the carcinogenic risk index (CRI) according to infant age group.

\begin{tabular}{|c|c|c|c|c|c|}
\hline \multirow{2}{*}{$\begin{array}{l}\text { Age Group } \\
\text { (Months) }\end{array}$} & \multirow{2}{*}{$\begin{array}{c}\text { Body Weight } \\
\text { (kg) }\end{array}$} & \multirow{2}{*}{$\begin{array}{l}\text { Milk Intake } \\
\text { (L/day) }\end{array}$} & \multicolumn{2}{|c|}{$\begin{array}{c}\text { EDI } \\
\text { (ng/kg Weight/Day) }\end{array}$} & \multirow{2}{*}{$\begin{array}{c}\text { CRI * } \\
(2 \mathrm{ng} / \mathrm{kg} \\
\text { Weight/Day) }\end{array}$} \\
\hline & & & Mean & Min-Max & \\
\hline 0 to 6 & 6.50 & 1.98 & $5.08 \pm 2.94$ & $1.52-20.18$ & Risk \\
\hline 7 to 12 & 8.99 & 2.35 & $4.68 \pm 2.21$ & $1.31-9.98$ & Risk \\
\hline 13 to 24 & 10.93 & 2.37 & $4.10 \pm 1.62$ & $1.08-6.33$ & Risk \\
\hline 25 to 36 & 13.24 & 2.02 & $1.81 \pm 0.52$ & $1.25-2.28$ & Potential risk \\
\hline
\end{tabular}

In the group aged 0- to 6-months old, infants were exclusively breastfed. However, as infant age increased, there was an introduction of complementary foods such as solid foods, infant formula, liquid milk, or dairy products that may contribute to AFM1 intake. To understand the impact of this, studies carried out in Nuevo Leon, Mexico (northeast region), analyzed several commercial follow-on infant formula and liquid milks (national origin), reporting AFM1 mean concentrations of $180 \mathrm{ng} / \mathrm{L}$ (range: 0-450 ng/L) and $520 \mathrm{ng} / \mathrm{L}$ (range: $100-1270 \mathrm{ng} / \mathrm{L})$ for these dairy products, respectively $[39,40]$, showing its relevance as a health risk when an infant diet is supplemented with these dairy products.

Limited studies exist estimating the daily intake of AFM1 in infants during the lactation period. The results obtained in this study are close to the EDI values found in Central Mexico (0.92-6.28 ng/kg weight/day) [38] and higher than those found in Lebanon (0.65-0.80 ng/kg weight/day) [33] or Morocco (0.35 ng/ kg weight/day) [39], but lower than those recorded in Egypt (52.68 ng/ kg weight/day) [41] or Tanzania (11.08 $\mathrm{ng} / \mathrm{kg}$ weight/day) [42].

The AFM1 intake was higher than the CRI of $2 \mathrm{ng} / \mathrm{kg}$ weight/day in infants aged 0 to 24-months old, indicating a high risk of AFM1 exposure for the infant population of northeast Mexico. 
These study results reflect the possible mother-to-infant contamination occurring through breast milk, thus increasing the risk by exposing the infants to AFM1 and possibly to other diverse carcinogenic toxins; therefore, it is imperative to establish health regulations to guarantee the quality and safety of food products that may be contaminated by aflatoxins.

\section{Conclusions}

Breast milk samples analyzed from lactating mothers in Monterrey, Nuevo Leon, Mexico, have shown a high occurrence of AFM1 (100\% of the samples) with different levels from 5.00 to $66.23 \mathrm{ng} / \mathrm{L}$, in 123 breast milk samples, with $13.01 \%$ of samples showing AFM1 levels higher than the upper limits $(25 \mathrm{ng} / \mathrm{L})$ established by the EU. Based on the average infant's body weight and average breast milk intake, the daily AFM1 intake and carcinogenic risk index were estimated in infants aged from 0- to 36-months old, with infants aged from 0 - to 24-months old determined to be at risk. These data indicate that lactating mothers in northeast Mexico have a high exposure to AFB1 and/or AFM1 through diet. This evidence strongly supports the need to establish public health programs to give nutrition education to women before and during breastfeeding periods, such that nursing women understand the importance of selecting food choices that lower susceptibility to AFM1 contamination and minimize its passage into breast milk.

\section{Materials and Methods}

\subsection{Breast Milk Samples}

Breast milk samples $(n=123)$ were obtained from breastfeeding women at regular medical visits to local health centers from the metropolitan area of Monterrey city, Nuevo Leon state (northeast region of Mexico), during the summer of 2021. Breast milk samples were collected under hygienic conditions in sterile glass bottles, protected from light, and stored until use at $-18{ }^{\circ} \mathrm{C}$. Before analysis, breast milk samples were thawed overnight at $4{ }^{\circ} \mathrm{C}$, and samples were centrifuged at $5000 \mathrm{rpm}$ for $10 \mathrm{~min}$. The upper fatty layer was discarded and $100 \mu \mathrm{L}$ from each defatted milk sample was used in ELISA assay. All the procedures followed in this study were executed according to the NOM-087-ECOL-SSA12002, which establishes the classification of hazardous biological-infectious waste and the specifications of its management [43].

\subsection{Quantitative AFM1 Determination by ELISA Assay}

AFM1 was detected via an ELISA assay, using the RIDASCREEN ${ }^{\circledR}$ kit Aflatoxin M1 (Art. No.: R1121, R-Biopharm AG, Darmstadt, Germany) based on antigen-antibody reactions, as Quevedo-Garza et al. (2018) has described. A 6-point calibration curve was performed in triplicate, with concentrations ranging from 0 to $80 \mathrm{ng} / \mathrm{L}(0,5,10,20,40$, and $80 \mathrm{ng} / \mathrm{L})$, using certified AFM1 standards. According to the manufacturer's description, the limit of detection was $5 \mathrm{ng} / \mathrm{kg}$. The resulting data were processed and calculated with the software RIDASOFT ${ }^{\circledR}$ Win.NET (v1.96) and reported as nanograms per liter (ng/L).

\subsection{Estimation of AFM1 Exposure in Infants}

To determine the exposure of the infant population to AFM1, the estimated daily intake (EDI) of AFM1 was calculated according to the equation proposed by Quevedo-Garza et al. (2020). Infants were grouped according to their age: 0- to 6-months old, 7- to 12-months old, 13- to 24-months old and 25- to 36-months old. The average breast milk intake and average body weight were obtained from data corresponding to the state of Nuevo León from the National Health and Nutrition Survey (ENSANUT) reported in 2018 [44].

According to the infants' age groups, milk intake was multiplied by the AFM1 concentration in breast milk, and then divided by infants' body weight, as stated in the following formula:

Estimated AFM1 daily intake $(\mathrm{ng} / \mathrm{kg}$ weight/day $)=\frac{\left[\text { AFM1 }\left(\frac{\mathrm{ng}}{\mathrm{L}}\right)\right] \times[\text { Milk intake }(\mathrm{L})]}{\text { Body weight }(\mathrm{kg})}$ 
where AFM1 is the average of AFM1 concentration in the analyzed samples, expressed in nanograms per liter (ng/L); milk intake is the average daily breast milk intake by the infant population, expressed in liters (L); and body weight is the average body weight of the infants from each age group, expressed in kilograms $(\mathrm{kg})$.

\subsection{Carcinogenic Risk Index}

A carcinogenic risk index (CRI) was established for the infants consuming AFM1 through breast milk by comparing the levels of estimated AFM1 daily intake (EDI) vs. the tolerable daily intake (TDI) of $2 \mathrm{ng} / \mathrm{kg}$ weight/day, as previously reported by KuiperGoodman (1994) and Quevedo-Garza et al. (2020).

\subsection{Statistical Analysis}

All samples were analyzed in duplicate and the AFM1 concentrations in breast milk were expressed as mean \pm standard deviation (SD), with minimum and maximum values. In order to evaluate the AFM1 concentrations within the different age-groups, one-way ANOVA was performed using the SPSS ${ }^{\circledR}$ v17.0 package to a 95\% level of significance, and Tukey adjustment was performed $(p<0.05)$.

Author Contributions: Methodology, R.S. and N.A.; data curation, A.d.J.G.; software, L.O.; formal analysis, A.d.J.G. and Z.J.-S.; writing-review and editing, R.S., A.T. and A.-J.T.; supervision, R.D. and M.S.; project administration, R.S. All authors have read and agreed to the published version of the manuscript.

Funding: This research was financed by the Support Program for Scientific and Technological Research-UANL (PAICYT), with the code number: SA1962-21. The determination of aflatoxins by enzyme-linked immunosorbent assay (ELISA) was carried out in the research laboratories of the Department of Biochemistry and Molecular Medicine of the Faculty of Medicine of the Autonomous University of Nuevo León, Mexico.

Institutional Review Board Statement: This study was conducted in accordance with the Declaration of Helsinki, and approved by the Institutional Review Board (or Ethics Committee) of FASPYN (21FaSPyN-SA-08; Date: 06/10/2021).

Informed Consent Statement: Informed consent was obtained from all subjects involved in the study.

Data Availability Statement: Not applicable.

Acknowledgments: We thank Olimpia Aguilar Hernández, Fernando Hernández Flores, and Marla Lucia González Mendez for the collection of milk samples.

Conflicts of Interest: The authors declare no conflict of interest.

\section{References}

1. Mosca, F.; Giannì, M.L. Human milk: Composition and health benefits. Pediatr. Med. E Chir. 2017, 39, 155. [CrossRef] [PubMed]

2. Lawrence, R.M.; Lawrence, R.A. Biochemistry of human milk. In Breastfeeding, 8th ed.; Elsevier: Philadelphia, PA, USA, 2016; ISBN 978-0-323-35776-0.

3. Samuel, T.; Zhou, Q.; Giuffrida, F.; Munblit, D.; Verhasselt, V.; Thakkar, S. Nutritional and non-nutritional composition of human milk is modulated by maternal, infant, and methodological factors. Front. Nutr. 2020, 7, 576133. [CrossRef] [PubMed]

4. Tauber, K.A. Human Milk and Lactation: Background, Physiology, Human Milk and Preterm Infant. Available online: https: / / emedicine.medscape.com/article/1835675-print (accessed on 20 December 2021).

5. World Health Organization. La Lactancia Materna Exclusiva Durante los Primeros 6 Meses es lo Mejor para Todos los Niños. Available online: https://apps.who.int/mediacentre/news/statements/2011/breastfeeding_20110115/es/index.html (accessed on 20 December 2021).

6. Yalçin, S.S.; Günes, B.; Yalçin, S. Influence of season and lactational stage on aflatoxin M1 and ochratoxin-A in human milk in a cohort study from southeastern region of Turkey. Int. J. Environ. Res. Public Health 2020. [CrossRef]

7. Ismail, A.; Gonçalves, B.; de Neeff, D.V.; Ponzilacqua, B.; Coppa, C.; Hintzsche, H.; Sajid, M.; Cruz, A.G.; Corassin, C.H.; Oliveira, C. Aflatoxin in foodstuffs: Occurrence and recent advances in decontamination. Food Res. Int. 2018, 113, 74-85. [CrossRef]

8. Martínez, H.Y.; Hernández, S.; Reyes, C.; Vázquez, G. El género aspergillus y sus micotoxinas en maíz en México: Problemática y perspectivas. Rev. Mex. Fitopatol. 2013, 31, 126-147. 
9. Cantú, F.; Aguilar, J.E.; de Leon, C.I.; Esparza, J.; Vallejo, B.; Gonzalez, A.F.; García, H.S.; Hernández, A. Occurrence and factors associated with the presence of aflatoxin M1 in breast milk samples of nursing mothers in central Mexico. Food Control 2016, 62, 16-22. [CrossRef]

10. Gong, Y.; Hounsa, A.; Egal, S.; Turner, P.C.; Sutcliffe, A.E.; Hall, A.J.; Cardwell, K.; Wild, C.P. Postweaning exposure to aflatoxin results in impaired child growth: A longitudinal study in Benin, West Africa. Environ. Health Perspect. 2004, 112, 1334-1338. [CrossRef]

11. Urrego, J.R.; Díaz, G.J. Aflatoxinas: Mecanismos de toxicidad en la etiología de cáncer hepático celular. Rev. Fac. Med. 2006, 54, $108-116$.

12. Wild, C.P.; Montesano, R. A model of interaction: Aflatoxins and hepatitis viruses in liver cancer aetiology and prevention. Cancer Lett. 2009, 286, 22-28. [CrossRef]

13. Gao, Y.; Bao, X.; Meng, L.; Liu, H.; Wang, J.; Zheng, N. Aflatoxin B1 and aflatoxin M1 induce compromised intestinal integrity through clathrin-mediated endocytosis. Toxins 2021, 13, 184. [CrossRef]

14. Yang, H.; Wang, Y.; Yu, C.; Jiao, Y.; Zhang, R.; Jin, S.; Feng, X. Dietary resveratrol alleviates AFB1-induced ileum damage in ducks via the Nrf2 and NF-kB/NLRP3 signaling pathways and CYP1A1/2 expressions. Agriculture 2022, 12, 54. [CrossRef]

15. Hernández, M.; Juan, A.; Moltó, J.C.; Mañes, J.; Juan, C. Evaluation of mycotoxins in infant breast milk and infant food, reviewing the literature data. Toxins 2021, 13, 535. [CrossRef] [PubMed]

16. Mahato, D.K.; Lee, K.E.; Kamle, M.; Devi, S.; Dewangan, K.N.; Kumar, P.; Kang, S.G. Aflatoxins in Food and Feed: An Overview on Prevalence, Detection and Control Strategies. Front. Microbiol. 2019, 10, 2266. [CrossRef] [PubMed]

17. Zinedine, A.; Salah, J.B.; Abbès, S.; Tantaoui, A. Aflatoxin M1 in Africa: Exposure assessment, regulations, and prevention strategies-A Review. Rev. Environ. Contam. Toxicol. 2021, 258, 73-108. [CrossRef] [PubMed]

18. Azarikia, M.; Mahdavi, R.; Nikniaz, L. Occurrence and dietary factors associated with the presence of aflatoxin B 1 and M 1 in breast milk of nursing mothers in Iran. Food Control 2017, 86, 207-213. [CrossRef]

19. Ortiz, J.; Jacxsens, L.; Astudillo, G.; Ballesteros, A.; Donoso, S.; Huybregts, L.; De Meulenaer, B. Multiple mycotoxin exposure of infants and young children via breastfeeding and complementary/weaning foods consumption in Ecuadorian highlands. Food Chem. Toxicol. 2018, 118, 541-548. [CrossRef] [PubMed]

20. Omar, S.S. Incidence of aflatoxin M1 in human and animal milk in Jordan. J. Toxicol. Environ. Health A 2012, 75, 1404-1409. [CrossRef] [PubMed]

21. Bogalho, F.; Duarte, S.; Cardoso, M.; Almeida, A.; Cabeças, R.; Lino, C.; Pena, A. Exposure assessment of portuguese infants to aflatoxin M1 in breast milk and maternal social-demographical and food consumption determinants. Food Control 2018, 90, 140-145. [CrossRef]

22. Galvano, F.; Pietri, A.; Bertuzzi, T.; Gagliardi, L.; Ciotti, S.; Luisi, S.; Bognanno, M.; La Fauci, L.; Iacopino, A.M.; Nigro, F.; et al Maternal dietary habits and mycotoxin occurrence in human mature milk. Mol. Nutr. Food Res. 2008, 52, 496-501. [CrossRef] [PubMed]

23. Tchana, A.N.; Moundipa, P.F.; Tchouanguep, F.M. Aflatoxin contamination in food and body fluids in relation to malnutrition and cancer status in Cameroon. Int. J. Environ. Res. Public Health 2010, 7, 78-88. [CrossRef] [PubMed]

24. Ishikawa, A.T.; Takabayashi, C.R.; Ono, E.Y.; Bagatin, A.K.; Rigobello, F.F.; Kawamura, O.; Hirooka, E.Y.; Itano, E.N. Exposure assessment of infants to aflatoxin M1 through consumption of breast milk and infant powdered milk in brazil. Toxins 2016, 8, 246. [CrossRef] [PubMed]

25. Schrenk, D.; Bignami, M.; Bodin, L.; Chipman, J.K.; del Mazo, J.; Grasl-Kraupp, B.; Hogstrand, C.; Hoogenboom, L.R.; Leblanc, J.-C.; EFSA Panel on Contaminants in the Food Chain; et al. Scientific opinion-Risk assessment of aflatoxins in food. EFSA J. 2020, 18, 6040. [CrossRef]

26. Fakhri, Y.; Rahmani, J.; Oliveira, C.; Franco, L.T.; Corassin, C.H.; Saba, S.; Rafique, J.; Khaneghah, A.M. Aflatoxin M1 in human breast milk: A global systematic review, meta-analysis, and risk assessment study (Monte Carlo simulation). Trends Food Sci. Technol. 2019, 88, 333-342. [CrossRef]

27. Dashti, B.; Al-Hamli, S.; Alomirah, H.; Al-Zenki, S.; Abbas, A.B.; Sawaya, W. Levels of aflatoxin M1 in milk, cheese consumed in Kuwait and occurrence of total aflatoxin in local and imported animal feed. Food Control 2009, 20, 686-690. [CrossRef]

28. Kunter, I.; Hürer, N.; Gülcan, H.O.; Öztürk, B.; Doğan, İ.; Şahin, G. Assessment of aflatoxin M1 and heavy metal levels in mothers breast milk in Famagusta, Cyprus. Biol. Trace Elem. Res. 2017, 175, 42-49. [CrossRef] [PubMed]

29. Bogalho, F. Exposure assessment of infants to Aflatoxin M1 in Breast milk and maternal social-demographical and food consumption determinants. Master Thesis, Escola Universitária Vasco da Gama, Coimbra, Portugal, 2017. Available online: http:/ /hdl.handle.net/10400.26/18655 (accessed on 24 January 2022).

30. Jafarian, A.; Pourradi, N. Aflatoxin M1 contamination of human breast milk in Isfahan, Iran. Adv. Biomed. Res. 2013, 2, 86 [CrossRef]

31. Diaz, G.J.; Sánchez, M.P. Determination of aflatoxin M1 in breast milk as a biomarker of maternaland infant exposure in Colombia. Food Addit. Contam. Part A Chem. Anal. Control Expo. Risk Assess. 2015, 32, 1192-1198. [CrossRef] [PubMed]

32. Elaridi, J.; Bassil, M.; Kharma, J.A.; Daou, F.; Hassan, H.F. Analysis of aflatoxin M1 in breast milk and its association with nutritional and socioeconomic status of lactating mothers in Lebanon. J. Food Prot. 2017, 80, 1737-1741. [CrossRef] [PubMed]

33. Abdulrazzaq, Y.M.; Osman, N.; Ibrahim, A. Fetal exposure to aflatoxins in United Arab Emirates. Ann. Trop. Paediatr. 2003, 22, 3-9. [CrossRef] [PubMed] 
34. Tomerak, R.H.; Shaban, H.H.; Khalafallah, O.A.; El Shazly, M.N. Assessment of exposure of Egyptian infants to aflatoxin M1 through breast milk. J. Egypt Public Health Assoc. 2011, 86, 51-55. [CrossRef] [PubMed]

35. Elzupir, A.O.; Abas, A.R.; Fadul, M.H.; Modwi, A.K.; Ali, N.M.; Jadian, A.F.; Ahmed, N.A.; Adam, S.Y.; Ahmed, N.A.; Khairy, A.A.; et al. Aflatoxin $\mathrm{M}_{1}$ in breast milk of nursing Sudanese mothers. Mycotoxin Res. 2012, 28, 131-134. [CrossRef] [PubMed]

36. Radonić, J.R.; Tanackov, S.D.; Mihajlović, I.J.; Grujić, Z.S.; Miloradov, M.B.; Škrinjar, M.M.; Sekulić, M.M. Occurrence of aflatoxin M1 in human milk samples in Vojvodina, Serbia: Estimation of average daily intake by babies. J. Environ. Sci. Health B 2017, 52, 59-63. [CrossRef] [PubMed]

37. Kuiper-Goodman, T. Prevention of human mycotoxicoses trough risk assesment and risk management. In Mycotoxins in Grain, Compounds other than Aflatoxin; Miller, J.D., Trenholm, H.L., Eds.; Eagan Press: St. Paul, MN, USA, 1994; pp. $439-469$.

38. Quevedo, P.A.; Amador, G.G.; Salas, R.; Ramos, E.G.; Trujillo, A.J. Aflatoxin M1 determination in infant formulae distributed in Monterrey, Mexico. Toxins 2020, 12, 100. [CrossRef]

39. Cherkani, A.; Ghanname, I.; Zinedine, A.; Sefrioui, H.; Qmichou, Z.; Mouane, N. Aflatoxin M1 prevalence in breast milk in Morocco: Associated factors and health risk assessment of newborns "CONTAMILK study". Toxicon 2020, 187, 203-208. [CrossRef]

40. Quevedo, P.A.; Amador, G.G.; Cantú, P.C.; Trujillo, J.A. Aflatoxin M1occurrence in fluid milk commercialized in Monterrey, Mexico. J. Food Saf. 2018, 38, e12507. [CrossRef]

41. El-Tras, W.F.; El-Kady, N.N.; Tayel, A.A. Infants exposure to aflatoxin $\mathrm{M}_{1}$ as a novel foodborne zoonosis. Food Chem. Toxicol. 2011, 49, 2816-2819. [CrossRef]

42. Magoha, H.; Kimanya, M.; De Meulenaer, B.; Roberfroid, D.; Lachat, C.; Kolsteren, P. Association between aflatoxin M1 exposure through breast milk and growth impairment in infants from Northern Tanzania. World Mycotoxin J. 2014, 7, 277-284. [CrossRef]

43. Secretaría de Medio Ambiente y Recursos Naturales, Norma Oficial Mexicana NOM-087-ECOL-SSA1-2002, Protección-Salud Ambiental-Residuos Peligrosos Biológico-Infecciosos-Clasificación y Especificaciones de Manejo, Last Revised January 2003. Available online: https:/ / www.dof.gob.mx/nota_detalle.php?codigo=704675\&fecha=17/02/2003\#: \{\}:text=NORMA\%20Oficial\% 20Mexicana\%20NOM\%2D087,Medio\%20Ambiente\%20y\%20Recursos\%20Naturales (accessed on 24 January 2022).

44. González, L.D.; Unar, M.; Quezada, A.D.; Bonvecchio, A.; Rivera, J. Situación de las prácticas de lactancia materna y alimentación complementaria en México: Resultados de la Ensanut 2018-2019. Salud Publica Mex. 2020, 62, 704-713. [CrossRef] 